\title{
Ecotoxicology of Copper in Horticultural Soils: A Review
}

\author{
Elhawat, N. ${ }^{1,4 *}$, Alshaal, T. A. ${ }^{2,4}$, Kratz, S. ${ }^{3}$, Domokos-Szabolcsy, É. ${ }^{4}$, El-Ramady, H. R. ${ }^{2,4,5}$, \\ Prokisch, J. ${ }^{5}$, Eszenyi, P. ${ }^{5}$, Sztrik, A. ${ }^{5}$, Babka, B. ${ }^{5}$ and Fári, M. ${ }^{4}$ \\ ${ }^{1}$ Biological and Environmental Sci. Dept., Faculty of Home Economics, Al-Azhar University, Egypt \\ ${ }^{2}$ Soil and Water Sciences Dept., Fac. of Agriculture, Kafrelsheikh Uni., Kafr El-Sheikh, Egypt \\ ${ }^{3}$ Institute for Crop and Soil Science, Julius Kühn-Institute (JKI), Federal Research Centre for Cultivated Plants, \\ Bundesallee 50, 38116 Braunschweig, Germany \\ ${ }^{4}$ Plant Biotechnology Dept., Debrecen Uni., Böszörményi Ú. 138, 4032 Debrecen, Hungary \\ ${ }^{5}$ Bio- and Environmental Enegetics Inst., Debrecen Uni., Böszörményi Ú. 138, 4032 Debrecen, Hungary
}

*Corresponding author: El-Ramady, H. (ramady2000@ gmail.com)

\begin{abstract}
Summary: Nowadays, the world is facing the problem of environmental pollution because of the increase of man's needs requires development in life activities, progress industrialization, transportation tools, enhancement of agriculture and exploitation of natural resources. Soil and water resources are extremely exposed to pollution from different aspects. Agrochemicals in particular, have created severe problems, since they release thousands of chemicals to the environment. Several studies on the effect of environmental pollutants on agroecosystem have been carried out. On the other hand, the importance of trace elements as environmental pollutants is well known and well documented in literature. $\mathrm{Cu}$ contamination to agricultural soils has been accelerated due to its wide and repeated use in agriculture and horticulture as fertilizers or fungicides to protect vines, citrus trees, and other fruit crops against fungus diseases. Applied Cu from different agrochemical sources to agroenvironment may be adsorbed and are transported to the groundwater table and pollute it besides polluting the soils. The use of Cu-based fungicides in vineyard soils is widely documented worldwide. It has been found that many countries contain concentrations in excess of 100 $m g \mathrm{~kg}^{-1}$. Importance of study of transport of $\mathrm{Cu}$ arises due to the fact that $\mathrm{Cu}$ is absorbed in soils and also reaches the groundwater table, thus polluting both soil and ground water. It is often more important to be able to estimate the mobile fraction, the readily soluble fraction, the exchangeable fraction, or the plant available fraction of $\mathrm{Cu}$ content of a soil as a more direct indication of the likelihood of deleterious or toxic effects on soils and groundwater. Therefore, the aim of present work was to highlight the behavior and ecotoxicological effects of copper on horticultural soils.
\end{abstract}

Keywords: Copper, horticultural soils, agrochemical, availability, ecotoxicology

\section{Introduction}

Copper $(\mathrm{Cu})$ is a redox-active transition element with roles in photosynthesis, respiration, $\mathrm{C}$ and $\mathrm{N}$ metabolism, and protection against oxidative stress. It forms highly stable complexes and participates in electron transfer reactions like $\mathrm{Fe}$. Divalent $\mathrm{Cu}$ is reduced readily to monovalent $\mathrm{Cu}$ which is unstable (Broadley et al. 2012). It is an essential micronutrient, a constituent of the plastocyanin chloroplast protein, and a component of the electron transport system linking Photosystems I and II in the photosynthetic process. Copper participates in protein and carbohydrate metabolism and $\mathrm{N}_{2}$ fixation. It is a component of some enzymes that reduce atoms of molecular oxygen (cytochrome oxidase, ascorbic acid oxidase, and polyphenol oxidase) and is involved in the desaturation and hydroxylation of fatty acids (Jones 2003). That means most of the functions of $\mathrm{Cu}$ as a plant nutrient are based on enzymatically bound $\mathrm{Cu}$ which catalyses redox reactions.
In redox reactions of the terminal oxidases, $\mathrm{Cu}$ enzymes react directly with molecular oxygen. Terminal oxidation in living cells is therefore catalysed by $\mathrm{Cu}$ and not by $\mathrm{Fe}$ (Broadley et al. 2012).

Due to versatile properties, $\mathrm{Cu}$ has a wide range of applications in different fields. It can be used for the production of various conductor materials such as fertilizers and pesticides. Due to its bacteriostatic properties, it can be also added to animal fodder (Kabata-Pendias 2011). It is well known that, the use of $\mathrm{Cu}$-based fungicides in vineyard soils is widely documented worldwide. Thus, vineyard soils in Greece, France, Slovenia, Portugal, and the Czech Republic have been found to contain concentrations in excess of $100 \mathrm{mg} \mathrm{kg}^{-1}$, above which the biological quality of the soils is substantially degraded through a strong effect on microbial action. Excessive concentrations of $\mathrm{Cu}$ can be hindered topsoil rooting in young vines. Also, there is the risk of $\mathrm{Cu}$ accumulating in river water or even river sediments by effect of erosion-induced mass movements in 
$\mathrm{Cu}$-contaminated soils, resulting in potential environmental problems (Fernández-Calviño et al. 2009a).

Therefore, this review focuses on the occurrence and behavior of $\mathrm{Cu}$ in horticultural soils and plants with relevance to the potential risks associated with $\mathrm{Cu}$ in the soils of horticultural properties to be developed for residential use.

\section{Typical Cu concentrations in soils}

It is well documented that, $\mathrm{Cu}$ has been part of the human civilizations since ancient times up to present days. This element has a history of use that is at least 10,000 years old, and estimates of its discovery place it at $9000 \mathrm{BC}$ in the Middle East; a Cu-pendant was found in northern Iraq that dates to 8700 BC (Rusjan 2012). Cu fabricated in Mesopotamia was quickly introduced to the the Egyptian Empire, where its use flourished thousands of years. These peoples used $\mathrm{Cu}$ for the fabrication of different jewels, ornaments, but also in the fields of armament and tools. They soon realized that pure $\mathrm{Cu}$, because of its softness, is not suitable for shaping tools used in agriculture, cultivation. Later, in the era of the Romans other metals, especially iron and bronze as the main metals in weaponry, gained in importance. In that time, $\mathrm{Cu}$ was first used also for architectural intentions, what can be witnessed on the roof sheathing of the Pantheon (Rusjan 2012).

The general values for the average total $\mathrm{Cu}$ contents in soils of different groups all over the world range between 14 and $109 \mathrm{mg} \mathrm{kg}^{-1}$ (Kabata-Pendias 2011). The concentration of $\mathrm{Cu}$ in a soil can be increased by applying fertilizers or organic wastes containing $\mathrm{Cu}$. Piggery wastes and digested urban sewage may contain relatively large concentrations of $\mathrm{Cu}$. The soils in horticultural areas may also contain elevated concentrations of $\mathrm{Cu}$ as a result of using $\mathrm{Cu}$ compounds to control plant pests and diseases (Cornforth et al. 2003). The regularity in large-scale $\mathrm{Cu}$ occurrence in soils indicates that two main factors including parent material and soil formation processes govern the initial $\mathrm{Cu}$ status of soils. Also, the clay fraction contributes significantly to the $\mathrm{Cu}$ content of soils. Other soil properties, such as Fe and Mn oxides, and base saturation, explain about $15-25 \%$ of all impact factors (Kabata-Pendias 2011).

It is showed that $\mathrm{Cu}$ concentrations varied from 7 to 490 $\mathrm{mg} \mathrm{kg}^{-1}$ in a survey of 43 horticultural soils in the Auckland area, New Zealand (Gaw 2002). Sites currently being used for orchards had an average concentration of $209 \mathrm{mg} \mathrm{kg}^{-1}$ $\mathrm{Cu}$, whereas vineyard soils had an average of $105 \mathrm{mg} \mathrm{kg}^{-1}$. About the background $\mathrm{Cu}$ concentrations in the soils of forest remnants were $10 \mathrm{mg} \mathrm{kg}^{-1}$ as reviewed by Cornforth et al. (2003). Generally, $\mathrm{Cu}$ is accumulated in the upper few centimeters of soils, however, due to its tendency to be adsorbed by soil clay minerals, carbonates, organic matter, and oxyhydroxides of $\mathrm{Mn}$ and Fe, it may be also accumulated in deeper soil layers. It is reported that, humic acids are to reveal a large binding capacity for this metal (Logan et al. 1997). On the other hand, $\mathrm{Cu}$ is a rather immobile element in soils and shows relatively little variation in total contents of soil profiles. Thus, the common characteristic of $\mathrm{Cu}$ distribution in soil profiles is its accumulation in the top horizons. This phenomenon is an effect of various factors, but above all, $\mathrm{Cu}$ concentration in surface soils reflects its bioaccumulation as well as its anthropogenic sources (Kabata-Pendias 2011). Concentrations of $\mathrm{Cu}$ in soil solution range from 0.5 to 135

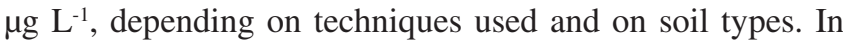
soil solution, it may occur as cations: $\mathrm{Cu}^{2+}, \mathrm{Cu}_{2}(\mathrm{OH})_{2}{ }^{2+}$, $\mathrm{CuOH}^{+}$, and as anions: $\mathrm{Cu}(\mathrm{OH})^{3-}, \mathrm{Cu}(\mathrm{OH})_{4}{ }^{2-}$, and $\mathrm{Cu}\left(\mathrm{CO}_{3}\right)_{2}{ }^{2-}$ (Kabata-Pendias and Sadurski 2004).

It is reported that, the main variables affecting the $\mathrm{Cu}$ mobility in soils include soil organic matter, dissolved organic matter, $\mathrm{pH}$, and $\mathrm{Cu}$ soil content. Overall solubility of both cationic and anionic forms of $\mathrm{Cu}$ decreases at about pH 7-8 (Ponizovsky et al. 2006). It was estimated also that hydrolysis products of $\mathrm{Cu}(\mathrm{CuOH})^{+}$and $\mathrm{Cu}^{2+}+2(\mathrm{OH})_{2}$ are the most significant species below $\mathrm{pH} 7$, while above $\mathrm{pH} 8$, anionic hydroxy complexes of $\mathrm{Cu}$ become important. The precipitation of $\mathrm{CuCO}_{3}$ in calcareous soils is a main process affecting the $\mathrm{Cu}$ activity in soil solution (Ponizovsky et al. 2007) as reviewed by (Kabata-Pendias 2011).

\section{Effects of Cu-agrochemicals on soils}

Soil contamination by $\mathrm{Cu}$ compounds has been the subject of detailed studies for several decades and a large database has been already collected and presented in a number of monographs and papers. In this context, several significant sources such as fertilizers, agrochemicals, manures, sewage sludge, industrial by-product wastes and the quality of irrigation waters have contributed to increased $\mathrm{Cu}$ levels to agricultural soils (Kabata-Pendias and Mukherjee 2007). $\mathrm{Cu}$ contamination to agricultural soils has been accelerated due to its wide and repeated use in horticulture and agriculture as fertilizers or fungicides to protect vines, citrus trees, and other fruit crops against fungus diseases (He et al. 2005). Due to a long history of vineyard or citrus production, $\mathrm{Cu}$ has accumulated in the soils. A large proportion of soils under citrus production contains total $\mathrm{Cu}$ content above $85 \mathrm{mg} \mathrm{kg}^{-1}$, the critical level for ecosystem health (Schuler and Hoang 2008). Soil pollution with $\mathrm{Cu}$ causes soil degradation, $\mathrm{Cu}$ phytotoxicity, and increased transport of $\mathrm{Cu}$ to surface and ground waters (He et al. 2010).

It is well documented that, the most important sources of $\mathrm{Cu}$ contamination include old mining area, deactivated $\mathrm{Cu}$ ore plant, nonferric metal mining, metal-processing industry, urban gardens, orchards, and parks, sludged, irrigated, or fertilized farmland, application of fungicides, vineyard soils, and military shooting range (Kabata-Pendias 2011). Dry and wet deposition around mining and smelting sites, wastewater irrigation, compost application, including municipal waste, sewage sludge or their combination, and spraying of heavy metal-containing pesticides or herbicides have been reported to contribute to the input of anthropogenic $\mathrm{Cu}$ and other heavy metals into agricultural soils (Yu et al. 2004). 
Table 1: Effects of soil texture, $\mathrm{pH}$, organic carbon (OC, \%), nitrogen content (N, \%) and effective cation exchange capacity (eCEC, $\left.\mathrm{cmol}_{\mathrm{c}} \mathrm{kg}^{-1}\right)$ on soil total $\mathrm{Cu}$ concentration ( $\mathrm{mg} \mathrm{Cu} \mathrm{kg}^{-1}$, as a range) in 6 vineyards locations around the world (from Mackie et al. 2012) comparing with mean of 95 vineyard soils from 6 different wine production areas in the NW Iberian Peninsula (from Soler-Rovira et al. 2013)

\begin{tabular}{|c|c|c|c|c|c|c|c|}
\hline $\begin{array}{l}\text { Country or } \\
\text { location } \\
\end{array}$ & $\begin{array}{c}\text { Total } \mathrm{Cu} \text { in control } \\
\text { soil }\left(\mathrm{mg} \mathrm{Cu} \mathrm{kg} \mathbf{~ k g}^{-1}\right)\end{array}$ & $\begin{array}{c}\text { Total } \mathrm{Cu} \text { in vineyard } \\
\text { soil }\left(\mathrm{mg} \mathrm{Cu} \mathrm{kg} \mathrm{kg}^{-1}\right) \\
\end{array}$ & Soil texture & Soil pH $\left(\mathrm{CaCl}_{2}\right)$ & $\begin{array}{l}\text { OC } \\
(\%) \\
\end{array}$ & $\mathbf{N}(\%)$ & $\begin{array}{c}\mathrm{eCEC} \\
\left(\mathrm{cmol}_{\mathrm{c}} \mathrm{kg}^{-1}\right) \\
\end{array}$ \\
\hline $\begin{array}{l}\text { NW Iberian } \\
\text { Peninsula }\end{array}$ & - & $11-1120$ & Sandy loam & 5.4 & 2.5 & - & 8.6 \\
\hline Germany & 74 & $142-513$ & Loam & 6.6 & 3.8 & 0.38 & 11.2 \\
\hline Germany & 105 & $159-435$ & Loam & 6.7 & 2.1 & 0.24 & 7.3 \\
\hline France & 23 & $201-689$ & Sandy loam & 6.8 & 2.1 & 0.17 & 17.2 \\
\hline Italy & 105 & $194-448$ & Loam & 7.3 & 9.1 & 0.22 & 16.1 \\
\hline Germany & 65 & $276-516$ & Silty clay loam & 7.3 & 5.9 & 0.40 & 29.2 \\
\hline Italy & 66 & $155-455$ & Loam & 7.5 & 5.6 & 0.08 & 15.3 \\
\hline
\end{tabular}

Control soil is the soil adjacent to the vineyard and for the NW Iberian Peninsula, the mean total of $\mathrm{Cu}^{\text {is }} 176 \mathrm{mg} \mathrm{Cu} \mathrm{kg}^{-1}$

It is reported that, $\mathrm{Cu}$ levels in plants ranging from 2 to $50 \mu \mathrm{g} \mathrm{g}^{-1}$ DW with $6 \mu \mathrm{g} \mathrm{g}{ }^{-1}$ considered as adequate in the shoots (Epstein and Bloom 2005). The amount of $\mathrm{Cu}$ contained in healthy plants varies considerably within this range and depends both on the species and the $\mathrm{Cu}$-feeding status. Typically, symptoms of deficiency start when $\mathrm{Cu}$ decreases below $5 \mu \mathrm{g} \mathrm{g}^{-1} \mathrm{DW}$ in vegetative tissues, whereas toxicity levels are observed above $20 \mu \mathrm{g} \mathrm{g}^{-1}$ DW or higher in the same tissue (Marschner 2002). However, it may be generally stated that total $\mathrm{Cu}$ contents below $10 \mathrm{mg} \mathrm{kg}^{-1}$ in different soils may indicate deficiency as reviewed by Kabata-Pendias (2011).

\section{Behavior of $\mathrm{Cu}$ in soils}

It is well known that, $\mathrm{Cu}$-based fungicides (such as the Bordeaux mixture, $\mathrm{CuSO}_{4}+\mathrm{Ca}(\mathrm{OH})_{2}$ ) have been intensively used in Europe since the end of the $19^{\text {th }}$ century to control vine (Vitis vinifera L.) fungal diseases, such as downy mildew caused by Plasmopara viticola. Besides vineyards, $\mathrm{Cu}$-based fungicides have also been extensively used such as in hop fields (Komárek et al. 2009), coffee (Loland and Singh 2004), apple (Li et al. 2005), avocado orchards (Van Zwieten et al. 2004) and during the cultivation of several vegetables such as tomatoes and potatoes (Adriano 2001) as reviewed by Komárek et al. (2010).

From the background $\mathrm{Cu}$ concentrations in unpolluted soils, it is found that this concentration is influenced by the parent material from which the soils are formed and reach an average of $30 \mathrm{mg} \mathrm{kg}^{-1}$. As of other metals, its solubility is greatly dependent on soil $\mathrm{pH}$ and will be most readily available at $\mathrm{pH}$ values below 6 (Table 1; Adriano 2001). For example, in acidic soils, $\mathrm{Cu}$ developed on granitic rocks, can migrate throughout soil profiles more easily and thus cause groundwater pollution (Nóvoa-Muñoz et al. 2007). $\mathrm{Cu}$ mobility in soils can increase at $\mathrm{pH}$ values above $\sim 7.5$ due to the solubilization of soil organic matter (SOM) and formation of $\mathrm{Cu}-\mathrm{SOM}$ complexes (Fernández-Calviño et al. 2009a). In general, $\mathrm{Cu}$ in soils is mostly associated with SOM, Fe-, Mn-(hydr)oxides and to a lesser extent with clay minerals through specific and non-specific adsorption (Fernández-Calviño et al. 2009b). However, SOM can influence the mobility of $\mathrm{Cu}$ by two different mechanisms: while particulate $\mathrm{SOM}$ will act as a sorbent for $\mathrm{Cu}$, soluble $\mathrm{SOM}$ will actually complex $\mathrm{Cu}$, increasing thus its solubility, especially at alkaline $\mathrm{pH}$ (above $~ 7.5$ ) (Martínez-Villegas and Martínez 2008). When $\mathrm{Cu}$ enters the soil, as a result of the wash-off from vine leaves (Paradelo et al. 2008) and accidental spills of the fungicides, its speciation rapidly changes and $\mathrm{Cu}$ is sorbed and co-precipitated in the soil (Komárek et al. 2010). This redistribution of $\mathrm{Cu}$ into less available chemical fractions of soils which decreases its mobility and bioavailability is referred to as aging (Sayen et al. 2009) as reviewed by Komárek et al. (2010).

\section{Bioavailability and toxicity of $\mathrm{Cu}$ in horticultural soils}

It is well known that, since about $1850, \mathrm{Cu}$ containing fungicides have been used to protect crops from fungal infections such as downy mildew (Plasmopara viticola). Thus, intensive and long term use of these fungicides has increased soil $\mathrm{Cu}$ concentrations and this is likely most pronounced in vineyards (Komárek et al. 2010). Nowadays, EC regulation 473/2002 (European Commission 2002) restricts the annual dose of applied $\mathrm{Cu}$ to $6 \mathrm{~kg} \mathrm{Cu} \mathrm{ha}^{-1}$, which corresponds to an annual accumulation of about $5 \mathrm{mg} \mathrm{Cu}$ $\mathrm{kg}^{-1}$ soil in the top $10 \mathrm{~cm}$ assuming no losses (Ruyters et al. 2013). Such a sustained application since $>150$ years would have increased soil $\mathrm{Cu}$ concentrations to $750 \mathrm{mg} \mathrm{Cu}$ $\mathrm{kg}^{-1}$ in unplowed vineyard soils, whereas plowing the first $30 \mathrm{~cm}$ after removing old vines (every 30-50 years) would yield a topsoil $\mathrm{Cu}$ concentrations of about $250 \mathrm{mg} \mathrm{Cu} \mathrm{kg}{ }^{-1}$. Measured $\mathrm{Cu}$ concentrations in vineyard soils range from 77 up to $3200 \mathrm{mg} \mathrm{Cu} \mathrm{kg}^{-1}$ (Komárek et al. 2010) and are above legislative limits affecting the sustainability and potentially the productivity of these agroecosystems as reviewed by Ruyters et al. (2013).

The phytotoxicity of $\mathrm{Cu}$ is the highest in acidic soils with a low cation exchange capacity. $\mathrm{Cu}$ phytotoxicity to agricultural plants grown on calcareous soils from former vineyards has been observed as well (Michaud et al. 2007). Although $\mathrm{Cu}$ concentrations in roots are a good indicator of 
$\mathrm{Cu}$ bioavailability in soils (Chopin et al. 2008), this time consuming approach is not suitable for routine analyses (Komárek et al. 2010). So, it is needed to point out that $\mathrm{Cu}$ uptake by roots is species-dependent and influenced by root type and size (i.e., fine vs. coarse roots) (Fig. 1; Chopin et al. 2008). Total $\mathrm{Cu}$ concentrations alone do not provide adequate information about the bioavailability of the metal in soils as well (Wightwick et al. 2008). On the other hand, water-soluble $\mathrm{Cu}$ concentrations alone do not give sufficient information either, because a portion of exchangeable $\mathrm{Cu}$ (not extractable by water) in soils can be easily taken up by roots (Komárek et al. 2010).
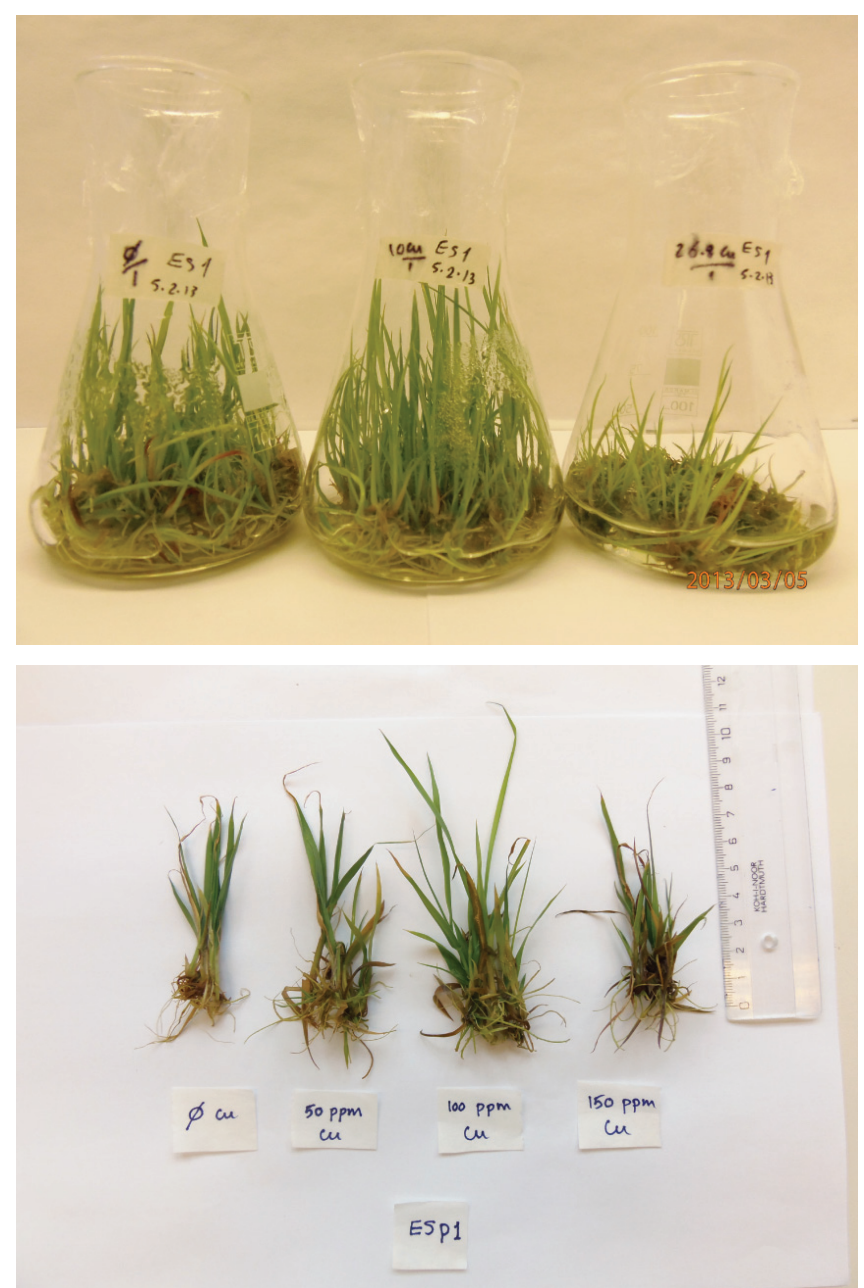

Fig. 1: Giant reed (Arundo donax L.) tolerant to different concentrations of $\mathrm{Cu}$ using liquid media. The Spanish ecotype (ESP 1) was used under different $\mathrm{Cu}$ concentartions from 0 to $26.8 \mathrm{mg} \mathrm{Cu} \mathrm{kg}^{-1}$ or from 0 to $150 \mathrm{ppm}$ in two different experiments (photos by T. Alshaal)

\section{Pollution of horticultural soils with $\mathrm{Cu}$}

As mentioned before, the mixtures of $\mathrm{Cu}$ sulphate and lime (Bordeaux mixture) have been widely used in pome and stone fruit orchards, vineyards and vegetable crops to control fungal diseases for over 100 years (Merry et al. 1983). However, foliar application of these fungicides leads to a significant input of $\mathrm{Cu}$ to soil, through direct application, dripping, or drift of excess sprays from leaf surfaces (Chaignon et al. 2003). Numerous studies indicated that long-term use of $\mathrm{Cu}$-based chemicals resulted in increased soil $\mathrm{Cu}$ concentrations, such as 29-131 mg kg-1 in India (Prasad et al. 1984); 100-1500 $\mathrm{mg} \mathrm{kg}^{-1}$ in France (Besnard et al. 1999) and 11-320 mg kg-1 in Australia (Wightwick et al. 2008). Consequently, some European countries have introduced restrictions on the use of $\mathrm{Cu}$ fungicides to protect the environment, which also satisfy eco-labelling requirements. For example, the Netherlands has banned $\mathrm{Cu}$ fungicides, while Switzerland has restricted the amount of $\mathrm{Cu}$ that can be applied per hectare (Table 2; Wang et al. 2009).

\section{Forms and accumulation of soil $\mathrm{Cu}$ in plants}

It is well know that, the difference between optimum and toxic concentrations of $\mathrm{Cu}$ in many economically important crops is very small. Normal and phytotoxic concentrations of $\mathrm{Cu}$ in plant leaves are 5-20 and 20-300 $\mathrm{mg} \mathrm{kg}^{-1}$, respectively although there are some species variations (Alloway 1995). Despite this, examples of $\mathrm{Cu}$ toxicity in plants are rare (Cornforth et al. 2003). The proportion of total soil $\mathrm{Cu}$ which is available to plants depends on soil composition and $\mathrm{pH}$. $\mathrm{Cu}$ is held strongly in soils containing relatively large concentrations of clay, organic material, or oxides of $\mathrm{Fe}$, $\mathrm{Al}$, and $\mathrm{Mn}$. These forms are largely unavailable to plants in the short term but may become slowly available if the more plant-available fractions are depleted (Cornforth et al. 2003). Availability of $\mathrm{Cu}$ is also greater in acid conditions although the link between $\mathrm{pH}$ and $\mathrm{Cu}$ availability is less marked than for other heavy metals. Liming an acid soil increases the amount of $\mathrm{Cu}$ adsorbed but does not necessarily decrease the amount of plant available $\mathrm{Cu}$ proportionally. This is because lime may increase the amount of $\mathrm{Cu}$ released by mineralisation of organic $\mathrm{Cu}$ (James and Barrow 1981) as reviewed by Cornforth et al. (2003).

It is well documented that, the bioavailability of soluble forms of $\mathrm{Cu}$ depends basically on both the molecular weight of $\mathrm{Cu}$ complexes and on the amounts present. Compounds of a low molecular weight liberated during decay of plant and animal residues as well as those applied with sewage sludge may greatly increase the availability of $\mathrm{Cu}$ to plants (KabataPendias 2011). It should be also emphasized, however, that concentrations of $\mathrm{Cu}$ in soil solutions are principally controlled by both the reactions of $\mathrm{Cu}$ with active groups at the surface of the solid phase and by reactions of $\mathrm{Cu}$ with specific substances. The behavior, phytobioavailability and toxicity of $\mathrm{Cu}$ are influenced by its species, and are not a function of its total concentration (Allen 1993). Several soil variables control the $\mathrm{Cu}$ solubility and thus bioavailability; these include soil $\mathrm{pH}$, soil organic matter, oxidation and reduction potential, soil texture, mineral composition, temperature, and water regime. The mobility of $\mathrm{Cu}$ is especially reduced at the presence of large mineral colloids with $\mathrm{Fe}-\mathrm{Al}$-oxyhydroxide coatings, by oxyhydroxide particles of $\mathrm{Al}, \mathrm{Mn}, \mathrm{Fe}$, and by organic matter (Kabata-Pendias and Sadurski 2004). 
Table 2: Total $\mathrm{Cu}$ concentration ( $\mathrm{mg} \mathrm{Cu} \mathrm{kg}^{-1}$ soil) and used methods in upper layers of vineyard soils as published in literature from 2007 to 2013

\begin{tabular}{|c|c|c|c|c|}
\hline Country/ location & Depth (cm) & $\begin{array}{c}\text { Total Cu } \\
\left(\mathrm{mg} \mathrm{Cu} \mathrm{kg}^{-1}\right)\end{array}$ & Method used & Reference \\
\hline Spain & $0-10$ & $125-603$ & $\mathrm{HNO}_{3}+\mathrm{HCl}+\mathrm{HF}$ & Nóvoa-Muñoz et al. (2007) \\
\hline Spain & $0-5$ & $42-583$ & $\mathrm{HNO}_{3}+\mathrm{HCl}+\mathrm{HF}$ & Pateiro-Moure et al. (2007) \\
\hline France & $0-10$ & $17-34$ & $\mathrm{HClO}_{4}+\mathrm{HF}$ & Dousset et al. (2007) \\
\hline Croatia & $0-20$ & $105-553$ & $\mathrm{HClO}_{4}+\mathrm{HNO}_{3}+\mathrm{HCl}+\mathrm{HF}$ & Miko et al. (2007) \\
\hline Slovenia & $0-20$ & $87-120$ & $\mathrm{HNO}_{3}+\mathrm{HCl}$ & Rusjan et al. (2007) \\
\hline Brazil & $0-5$ & $37-3216$ & $\mathrm{HNO}_{3}+\mathrm{HClO}_{4}+\mathrm{HF}$ & Mirlean et al. (2007) \\
\hline Spain & $0-20$ & $35-550$ & $\mathrm{HNO}_{3}+\mathrm{HCl}+\mathrm{HF}$ & Díaz-Raviña et al. (2007) \\
\hline Brazil & $0-20$ & $51-665$ & $\mathrm{H}_{2} \mathrm{O}_{2}+\mathrm{HClO}_{4}+\mathrm{HF}$ & Casali et al. (2008) \\
\hline France & $0-10$ & $89-243$ & $\mathrm{HNO}_{3}$ & Probst et al. (2008) \\
\hline France & $5-10$ & 232 & $\mathrm{HNO}_{3}+\mathrm{HCl}+\mathrm{HF}$ & Chopin et al. (2008) \\
\hline Italy & n.a. & $215-372$ & $\mathrm{HNO}_{3}+\mathrm{HCl}$ & Dell'Amico et al.(2008) \\
\hline Spain & $0-5$ & $42-583$ & $\mathrm{HNO}_{3}+\mathrm{HCl}+\mathrm{HF}$ & Fernández-Calviño et al. (2008a) \\
\hline Spain & $0-20$ & $79-130$ & $\mathrm{HNO}_{3}+\mathrm{HCl}+\mathrm{HF}$ & Fernández-Calviño et al. (2008b) \\
\hline Spain & $0-20$ & $25-272$ & $\mathrm{HNO}_{3}+\mathrm{HCl}+\mathrm{HF}$ & Fernández-Calviño et al. (2008c) \\
\hline Spain & $0-20$ & $61-434$ & $\mathrm{HNO}_{3}+\mathrm{HCl}+\mathrm{HF}$ & Fernández-Calviño et al. (2008d) \\
\hline Brazil & $0-5$ & $433-517$ & $\mathrm{HNO}_{3}+\mathrm{HClO}_{4}+\mathrm{HF}$ & Mirlean et al. (2009) \\
\hline Spain & $0-20$ & $55-112$ & $\mathrm{HNO}_{3}+\mathrm{HCl}+\mathrm{HF}$ & Fernández-Calviño et al. (2009a,b) \\
\hline Slovenia & $0-45$ & 364 & n.a. & Pociecha and Lestan (2009) \\
\hline NW Spain & n.a. & $100-268$ & n.a. & Fernández-Calviño et al. (2010) \\
\hline Italy & n.a. & 93 & n.a. & Provenzano et al. (2010) \\
\hline Spain & n.a. & $22.5-66.8$ & n.a. & Herrero-Hernández et al. (2011) \\
\hline NW Iberian Peninsula & $0-20$ & 176 & $\mathrm{HNO}_{3}+\mathrm{HCl}+\mathrm{HF}$ & Soler-Rovira et al. (2013) \\
\hline Different * & $0-10$ & $435-689$ & Aqua regia extraction & Ruyters et al. (2013) \\
\hline
\end{tabular}

Compiled from Komárek et al. (2010), Mackie et al. (2012), Soler-Rovira et al. (2013) and Ruyters et al. (2013)

n.a., not available

* mean of soil samples from France (1 site), Germany (3 sites) and from Italy (2 sites)

The affinity of $\mathrm{Cu}$ to separate soil fractions decreases in the following order: Mn-(hydr)oxides $>$ SOM $>$ Fe-(hydr) oxides > clay minerals (Bradl 2004). Dissolved organic matter has a great affinity to fix $\mathrm{Cu}$ and thus to inhibit its sorption in soils. These phenomena are attributed to the formation of soluble $\mathrm{Cu}$-organic complexes (Zhou and Wong 2003). In mineral soils, natural attenuation of $\mathrm{Cu}$ occurs as an effect of $\mathrm{Cu}$ substituting for $\mathrm{Ca}$ in calcites present in calcareous soils and as precipitation of $\mathrm{Cu}(\mathrm{OH})_{2}$ and/or $\mathrm{Cu}_{2}(\mathrm{OH})_{2} \mathrm{CO}_{3}$ in other soils (Ma et al. 2006). It is observed that the long-term application of $\mathrm{Cu}$ fertilizers resulted in a great $\mathrm{Cu}$ accumulation in surface soil (0-15 $\mathrm{cm}$ ) due to its low mobility, since a great proportion of added $\mathrm{Cu}$ was bound to mineral soil fractions (Wei et al. 2007). The more readily plant available forms include $\mathrm{Cu}$ ions in solution, soluble organic- $\mathrm{Cu}$ complexes, and $\mathrm{Cu}$ on the soil's exchange complex (Alloway 1995). However, Bolan et al. (2003) distinguish between $\mathrm{Cu}$ adsorbed on soluble organic matter and free $\mathrm{Cu}^{2+}$ ions in the soil solution: the former may increase the mobility of $\mathrm{Cu}$ in the soil while the latter represents the plant available fraction as reviewed by Cornforth et al. (2003).

It is reported that, soil carbonates proved to be another important factor controlling $\mathrm{Cu}$ mobility (and thus bioavailability) in soils. It is also found that, the activity of $\mathrm{Cu}$ in calcareous soils is to a great extent controlled by the surface precipitation of $\mathrm{CuCO}_{3}$ (Ponizovsky et al. 2007). This is especially important in alkaline soils containing high concentrations of carbonates, which is the case for many vineyards. The retention of $\mathrm{Cu}$ in calcareous soils through co-precipitation with carbonates is associated with the release of $\mathrm{Ca}^{2+}, \mathrm{Mg}^{2+}, \mathrm{Na}^{+}$and $\mathrm{H}^{+}$into the soil solution at equimolar ratios (Ponizovsky et al. 2007). The precipitation of newly formed $\mathrm{Cu}$ phases in the soil presents thus an important retention mechanism of $\mathrm{Cu}$ retention in soils. The solubility of $\mathrm{Cu}$ minerals in soils decreases in the following order: $\mathrm{CuCO}_{3}>\mathrm{Cu}_{3}(\mathrm{OH})_{2}\left(\mathrm{CO}_{3}\right)_{2}$ (azurite) $>\mathrm{Cu}(\mathrm{OH})_{2}>$ $\mathrm{Cu}_{2}(\mathrm{OH})_{2} \mathrm{CO}_{3}$ (malachite) $>\mathrm{CuO}$ (tenorite) $>\mathrm{CuFe}_{2} \mathrm{O}_{4}$ (cupric ferrite). Copper sulfates, such as $\mathrm{CuSO}_{4}$ (chalcocyanite) and $\mathrm{CuSO}_{4} \cdot 5 \mathrm{H}_{2} \mathrm{O}$ (chalcanthite), are highly soluble and require very high $\mathrm{Cu}$ concentrations to form in soils (Lindsay 1979) as reviwed by Komárek et al. (2010).

In excessive quantities $\mathrm{Cu}$ becomes toxic as it interferes with photosynthetic and respiratory processes, protein synthesis and development of plant organelles (Upadhyay and Panda 2009). Specifically excess $\mathrm{Cu}$ can cause chlorosis, inhibition of root growth and damage to plasma membrane permeability, leading to ion leakage (Bouazizi et al. 2010). Reports are also available on induced deficiency of various minerals content under $\mathrm{Cu}$ toxicity (Lequeux et al. 2010). Apart from this, the information on plant metabolism is sporadic. Hence, efforts have been made to establish the toxic level of $\mathrm{Cu}$ on mung bean plants. It is found that, low $\mathrm{Cu}$ concentration $\left(50 \mathrm{mg} \mathrm{kg}^{-1}\right)$ had stimulatory effect on growth, dry matter yield and mineral nutrient content of mung bean. Whereas, $\mathrm{Cu}$ application beyond these levels (100-250 mg 
Table 3: Some hyperaccumulators of copper from Democratic Republic of Congo (Zaire)

\begin{tabular}{|l|c|c|c|}
\hline Plant species & Family of plant & Maximum Cu concentration $\mathbf{( m g ~ \mathbf { ~ k g } ^ { - 1 } )}$ & References \\
\hline Pandiaka metallorum & Amaranthaceae & 6,270 & Malaisse et al. (1979) \\
\hline Anisopappus davyi & Compositae or Asteraceae & 3,504 & Malaisse et al. (1994) \\
\hline Ascolepis metallorum & Cyperaceae & 1,211 & Malaisse et al. (1994) \\
\hline Vigna dolomitica & Fabaceae or Leguminosae & 3,000 & Malaisse \& Gregoire (1978) \\
\hline Haumaniastrum robertii & Lamiaceae or Labiatae & 2,070 & Brooks (1977) \\
\hline Actiniopteris sp. & Pteridaceae & 3,535 & Malaisse et al. (1994) \\
\hline Buchnera henriquesii & Scrophulariaceae & 3,520 & Brooks et al. (1987) \\
\hline Triumfetta dekindtiana & Liliaceae & 1,283 & Brooks et al. (1987) \\
\hline
\end{tabular}

Compiled from Reeves (2006)

$\mathrm{kg}^{-1}$ ) adversely affected the growth, dry matter yield and nutrient content (Manivasagaperumal et al. 2011).

Copper can be presented in several insoluble forms; (1) adsorbed on surface of metal oxides, clay minerals, humic substances and organo-mineral complexes, (2) in structure of secondary minerals or in amorphous iron and manganese oxides; (3) or associated with antigenic sulfides. Gunkel et al. (2003) found that applied $\mathrm{Cu}$ was mostly concentrated in the $\mathrm{MnO}_{x}, \mathrm{FeO}_{x}$ and organic soil fractions. Although the total copper levels were quite low on $\mathrm{Cu}$-enriched plots, ranging from $68-135 \mathrm{mg} \mathrm{kg}^{-1}$, anthropogenic copper in soil influenced the maize crop yield. The recommended method for determine the real bioavailability nowadays is the sequential extraction method and the plant bioassay.

Most of the cases of hyperaccumulation of $\mathrm{Cu}$ and $\mathrm{Co}$ have been reported from the metalliferous soils of the Democratic Republic of Congo (formerly Zaire), where the two metals occur together at elevated levels in the soils, but in widely varying proportions (Reeves 2006). A few other records of plants with $>1000 \mathrm{mg} \mathrm{kg}^{-1} \mathrm{Cu}$ from $\mathrm{Cu}$-mineralized areas (Dykeman and De Sousa 1966) should be reinvestigated in detail. Normal concentrations of $\mathrm{Co}$ and $\mathrm{Cu}$ in plants are in the ranges $0.03-2$ and $5-25 \mathrm{mg} \mathrm{kg}^{-1}$, respectively. The tupelo or black gum of the southeastern United States (Nyssa sylvatica) is remarkable in being able to accumulate as much as $845 \mathrm{mg} \mathrm{kg}^{-1}$ Co from normal soils (Brooks 1977). Plant $\mathrm{Cu}$ concentrations are controlled within a remarkably narrow range, and $\mathrm{Cu}$ concentrations above $100 \mathrm{mg} \mathrm{kg}^{-1}$ are rarely found in carefully washed plant leaves, even in the presence of high soil $\mathrm{Cu}$. The $\mathrm{Cu}$ hyperaccumulators have been found in more than a dozen plant families; some examples are given in Table 3, and a more complete listing can be found in Reeves and Baker (2000). It should also be noted that most of the $\mathrm{Cu}$ accumulators are not restricted to metalliferous soils. Therefore, great care needs to be taken in selecting seed of any of these species for studies connected with metalaccumulation experiments or with studies of their potential for phytoremediation (Reeves 2006).

\section{Loading limits of $\mathrm{Cu}$ in soils}

Most studies are limited to the total soil $\mathrm{Cu}$ concentration and its distribution among soil components in the orchards receiving long-term application of $\mathrm{Cu}$ fungicides
(Fernández-Calviño et al. 2008c). As fungicides are applied to control fungal diseases, they will also affect beneficial soil fungi and other soil organisms. Therefore, in many regions of the world there are increasing concerns that $\mathrm{Cu}$ may reach the concentrations in orchard soils toxic to soil organisms, or even phytotoxicity (Viti et al. 2008). Although the total soil $\mathrm{Cu}$ concentration is a useful indicator of soil deficiency and/or contamination, it does not provide enough information about its environmental impact (Bending et al. 2004). Since biological properties are sensitive to change, they are being considered to be suitable indicators of environmental impact for properly complementing the soil physicochemical properties as reviewed by Wang et al. (2009).

Increased $\mathrm{Cu}$ levels in vineyard soils up to $246 \mathrm{mg}$ $\mathrm{kg}^{-1}$ affected the $\mathrm{Cu}$ accumulation up to $209 \mathrm{mg} \mathrm{kg}^{-1}$ in river sediments (Fernandez- Calvino et al. 2008b). In the surface soil layer of vineyards, after 50-100 years of applied fungicides, the content of $\mathrm{Cu}$ forms dissolved by various extractants were as follows (in $\mathrm{mg} \mathrm{kg}^{-1}$ ): aqua regia 220, DTPA 82.5, and $\mathrm{CaCl}_{2} 0.23$ (Deluisa et al. 1996). The maximum allowable loading of $\mathrm{Cu}$ with wastes to arable soils of the EU countries is estimated at $12 \mathrm{~kg}$ $\mathrm{ha}^{-1}$ year ${ }^{-1}$. Ranges of maximum allowable concentration (MAC) values commonly cited in literature range from 20 to $100 \mathrm{mg} \mathrm{kg}^{-1}$ (Kabata-Pendias and Sadurski 2004). Precautionary values for $\mathrm{Cu}$ in Germany are established for soils of various textures as follows (in $\mathrm{mg} \mathrm{Cu} \mathrm{kg} \mathrm{kg}^{-1}$ ): clay, 100; loam, 60; and sand, 30 (Eckel et al. 2005) as reviewed by Kabata-Pendias (2011).

It is well documented that, $\mathrm{Cu}$ reveals a strong affinity for $\mathrm{S}$, hence its principal minerals are chalcopyrite, $\mathrm{CuFeS}_{2}$; bornite, $\mathrm{Cu}_{5} \mathrm{FeS}_{4}$; chalcocite, $\mathrm{Cu}_{2} \mathrm{~S}$; and covellite, $\mathrm{CuS}$. During the weathering of copper sulfides, $\mathrm{Cu}$ is incorporated in oxide and carbonate minerals of which cuprite, $\mathrm{Cu}_{2} \mathrm{O}$; tenarite, $\mathrm{CuO}$; malachite, $\mathrm{Cu}_{2} \mathrm{CO}_{3}(\mathrm{OH})_{2}$; and azurite, $\mathrm{Cu}_{2}\left(\mathrm{CO}_{3}\right)_{2}(\mathrm{OH})_{2}$ are the most common. $\mathrm{Cu}$ is often associated with sphalerite, $\mathrm{ZnS}$; pyrite, $\mathrm{FeS}$; and galena, $\mathrm{PbS}$. Its ores are commonly found in acid igneous rocks and various sedimentary deposits (Table 4; Kabata-Pendias 2011). Cu has a high affinity for peptide and sulphhydryl groups, and thus to cysteine-rich proteins, as well as also for carboxylic and phenolic groups. Therefore, more than $98 \%$ of the $\mathrm{Cu}$ in plants is present in complexed forms and the concentrations of free $\mathrm{Cu}^{2+}$ and $\mathrm{Cu}^{+}$ is extremely low in the cytoplasm (Broadley et al. 2012). 
Table 4: Selected properties of copper comparing with sulfur as an element-based fungicides for some physical, chemical and biological properties

\begin{tabular}{|c|c|c|}
\hline Properties or items (unit) & Sulphur (S) & Copper $(\mathbf{C u})$ \\
\hline Name origin & Latin word sulfur (brimstone) & Latin Cuprum (isle of Cyprus) \\
\hline Discovery or discoverer of essentiality (year) & von Sachs, Knop (1865) & Sommer (1931) \\
\hline World mine production in 2012 (metric tons) & $70,000 \times 10^{3}$ & $17,100 \times 10^{3}$ \\
\hline Abundance in the Earth's crust & $0.06-0.1(\%)$ & $55 \mathrm{mg} \mathrm{kg}^{-1}$ \\
\hline Abundance or usual soil content & $0.01-0.1(\%)$ & $20 \mathrm{mg} \mathrm{kg}^{-1}$ \\
\hline Ranking in order of abundance in earth crust & 14 & 26 \\
\hline Most important minerals & $\begin{array}{c}\text { Gypsum }\left(\mathrm{CaSO}_{4} 2 \mathrm{H}_{2} \mathrm{O}\right), \text { Pyrite }\left(\mathrm{FeS}_{2}\right), \\
\text { Chalcopyrite }(\mathrm{CuFeS}) \\
\text { Galena }(\mathrm{PbS}) \\
\end{array}$ & $\begin{array}{l}\text { Chalcopyrite } \mathrm{CuFeS}_{2} \text {, Malachite } \mathrm{Cu}_{2}(\mathrm{OH})_{2}\left(\mathrm{CO}_{3}\right) \text {, } \\
\text { Cuprite } \mathrm{Cu}_{2} \mathrm{O}\end{array}$ \\
\hline Most important sources & Iron sulfide and sulfate & Copper sulfide, sulfate and carbonate \\
\hline Most important uses & Matches, gunpowder, medicines & Fertilizers, pesticides, motors and electrical industry \\
\hline Common valence states & $-2,0,+2,+4,+6$ & +1 and +2 \\
\hline Ionic Radius $\left(\mathrm{A}^{\circ}\right)$ & 0.37 & 1.28 \\
\hline Electronegativity (according to Pauling scale) & 2.58 & 1.90 \\
\hline Atomic Number & 16 & 29 \\
\hline Atomic Mass (atomic mass unit) & 32.06 & 63.54 \\
\hline Atomic Radius $\left(\mathrm{A}^{\circ}\right)$ & 0.88 & 1.57 \\
\hline Density at $20^{\circ} \mathrm{C}\left(\mathrm{g} \mathrm{cm}^{-3}\right)$ & 2.07 & 8.94 \\
\hline Boiling point $\left({ }^{\circ} \mathrm{C}\right)$ & 444.6 & 2595 \\
\hline Melting point $\left({ }^{\circ} \mathrm{C}\right)$ & 112.8 & 1083 \\
\hline Crystal Structure & Orthorhombic & Cubic \\
\hline Functions in Plants & $\begin{array}{c}\text { Component of amino acids, glucosides, } \\
\text { coenzyme A, vit. B1 }\end{array}$ & $\begin{array}{c}\text { constituent of protein and many superoxide } \\
\text { dismutases (SOD) }\end{array}$ \\
\hline Principal forms for plant uptake & Sulfate $\mathrm{SO}_{4}^{-2}$ anion & Cupric cation $\left(\mathrm{Cu}^{2+}\right)$ \\
\hline Essentiality for animals and plants & Essential for both & Essential for both \\
\hline Typical sufficient concentration (plant shoot) & $1,000 \mathrm{mg} \mathrm{kg}^{-1} \mathrm{DM}$ & $6 \mathrm{mg} \mathrm{kg}^{-1} \mathrm{DM}$ \\
\hline Critical level in plant leaf (DW, dry weight) & $0.10-0.50(\%)$ & $1.0-5 \mathrm{mg} \mathrm{kg}^{-1}$ \\
\hline Toxic level in plant leaf (DW, dry weight) & $0.5-0.7(\%)$ & $15-30 \mathrm{mg} \mathrm{kg}^{-1}$ \\
\hline Uptake by plants & Active $\left(\mathrm{SO}_{4}^{-2}\right)$ & Active \\
\hline Major antagonistic elements & $\mathrm{As}, \mathrm{Fe}, \mathrm{Pb}, \mathrm{Mo}$, and $\mathrm{Se}$ & $\mathrm{Ca}, \mathrm{Mg}, \mathrm{P}$, and $\mathrm{N}$ \\
\hline Major synergistic elements & $\mathrm{F}$ and $\mathrm{Fe}$ & $\mathrm{Ca}, \mathrm{P}$, and $\mathrm{N}$ \\
\hline Mobility in plant & Moderately mobile & Immobile \\
\hline Movement in soil & Mass flow $\left(\mathrm{SO}_{4}^{-2}\right)$ & Mass flow \\
\hline Hudroponic nutrient concentration in solution & $70-150 \mathrm{mg} \mathrm{S} \mathrm{L}^{-1}$ & $0.01-0.1 \mathrm{mg} \mathrm{Cu} \mathrm{L}^{-1}$ \\
\hline
\end{tabular}

Compiled from Jones (2003), Jones (2005), Kabata-Pendias and Mukherjee (2007), White and Brown (2010), Kabata-Pendias (2011), Kirkby (2012), USGS (2013)

\section{Effects of $\mathrm{Cu}$ on soil organisms in horticultural soils}

It is found that, there were a number of basic criteria that a microbiological property might be expected to fulfill as an indicator in monitoring soil pollution by metals or other pollutants (Brooks 1995). Soil microbial biomass is considered to be a transformation agent of soil organic materials and a labile pool for plant nutrients. Hence, the change of the soil microbial biomass could lead to a change in the rate of nutrient cycling and the size of the nutrient pool. It is suggested that, soil $\mathrm{C}$ mineralization and linked parameters such as $\mathrm{CO}_{2}-\mathrm{C}$ production per unit biomass $\mathrm{C}$ and unit time (biomass specific respiration rate) might be useful as indicators for the change of soil function (Brooks 1995). Soil enzyme activities are also useful for detecting changes in soil quality, as they underpin nutrient cycling, and also function as signals of altered microbial community structure caused by environmental impact (Wang et al. 2009).
Because of the human and environmental health hazards that may arise from this pollution, setting soil- $\mathrm{Cu}$ limits and adequatemanagement practices are necessary to reach sustainability in this type of crop. High $\mathrm{Cu}$ contents can harm soil microbial communities, which are the main agents responsible for long-term sustainability of soil ecosystems (Nannipieri et al. 2003). Some studies have evaluated the effects of $\mathrm{Cu}$ on enzymatic activities (Fernández-Calviño et al. 2010a), microbial community structure (FernándezCalviño et al. 2010b), and bacterial community tolerance (Fernández-Calviño et al. 2011a) in vineyard soils. However, the establishment of limits for $\mathrm{Cu}$ accumulation using microbial indicators is difficult because of the confounding effects of soil factors such as texture, $\mathrm{pH}$, and organic matter content (Fernández-Calviño et al. 2011b) as reviewed by (Soler-Rovira et al. 2013).

It is reported that, toxic effects of $\mathrm{Cu}$ on the microbial communities in vineyard soils have been observed and the enzyme activities in soil were affected at and above total 
concentrations of $150-200 \mathrm{mg} \mathrm{Cu} \mathrm{kg} \mathrm{kg}^{-1}$ soil (FernándezCalviño et al. 2010a), whereas nitrification was impaired in soils contaminated up to $380 \mathrm{mg} \mathrm{Cu} \mathrm{kg}^{-1}$ (Baroux 1972). Evidence for increased $\mathrm{Cu}$ tolerance of the microbial community in response to the $\mathrm{Cu}$ contamination has also been reported in such soils (Diaz-Ravina et al. 2007) as reviewed by Ruyters et al. (2013). On the other hand, there is evidence that earthworms (Martin 1986) and soil microorganisms (Aoyama and Nagumo 1997) are less active in $\mathrm{Cu}$-rich soils than in those with concentrations of $\mathrm{Cu}$ in the normal range (2-30 $\mathrm{mg} \mathrm{kg}^{-1}$ ) (Cornforth et al. 2003). Earthworm populations have been proposed as indicators of the degree of $\mathrm{Cu}$ contamination in orchard and vineyard soils (Paoletti et al. 1998). This approach assumes that earthworms and higher plants are similar in their sensitivity to $\mathrm{Cu}$ or that decreased earthworm activity will damage soil structure to the extent that plant growth suffers (Cornforth et al. 2003).

\section{Environmental risks}

The intensive and long-term use of copper salts, promoted, in viticulture over the years, $\mathrm{Cu}$ accumulation in soils. $\mathrm{Cu}$ is a heavy metal toxic for aquatic and soil organisms, bacteria, fungi and plants it also has a negative effect on human health (Turnlund et al. 2004). In soil, $\mathrm{Cu}$ is restricted mainly in the top layer because of its ability to tightly bind with carbonates, clay minerals, hydrous oxides of $\mathrm{Al}, \mathrm{Fe}$ and $\mathrm{Mn}$ and organic matter (Mengel et al. 2001). Despite its environmental and agricultural importance, the concentration, distribution and fractionation of anthropogenic, and naturally occurring, $\mathrm{Cu}$ in soils is poorly known. Although the total $\mathrm{Cu}$ content in soils is a useful indicator of soil deficiency and/or contamination, it does not provide enough information about its environmental impact (Pietrzaka and McPhail 2004). Sorption on SOM by means of complexation especially with humic and fulvic acids presents possibly the most important retention mechanism for $\mathrm{Cu}$ in soils (Strawn and Baker 2009). Its association with SOM through inner-sphere complexation (e.g., bidentate inner-sphere coordination with carboxyl or amine ligands; Strawn and Baker 2008) results in its lower toxicity compared to free $\mathrm{Cu}^{2+}$ (Karlsson et al. 2006). Additionally, $\mathrm{Cu}$-rich SOM is less vulnerable to biodegradation (Parat et al. 2002). In most cases, the sorption of $\mathrm{Cu}$ in soils follows well either the Langmuir or the Freundlich isotherm as reviewed by Komárek et al. (2010).

Contents of $\mathrm{Cu}$ are closely associated with soil texture and usually are the lowest in light sandy soils and the highest in loamy soils. It is found that, $\mathrm{Cu}$ toxicity seems to be related to soil texture and a toxicity threshold was established only in light textured soils, for nonbearing potted grapevine and pear plants at a concentration of DTPA-extractable $\mathrm{Cu}>141$ and $350 \mathrm{mg} \mathrm{kg}^{-1}$, respectively, while in clay-loam soils, both the fruit species showed the possibility to tolerate levels of DTPAextractable $\mathrm{Cu}$ as high as $1000 \mathrm{mg} \mathrm{kg}^{-1}$ with no symptoms on shoot growth (Toselli et al. 2009). Cu availability to biota (as a nutrient or toxin) and its mobility are the most important factors to be considered when assessing its effect on the soil environment. Since $\mathrm{Cu}$ bioavailability is influenced not only by soil physical and chemical properties, but also by environmental factors such as climate, biological population, and type and source of contaminants, correlation between total and bioavailable $\mathrm{Cu}$ cannot be predicted accurately (Pietrzaka and McPhail 2004).

$\mathrm{Cu}$ must be absorbed in small amounts on a daily basis to maintain good health. A daily dietary intake of 1-2 mg is required. However, high levels of $\mathrm{Cu}$ can be harmful to health. Inhaling high levels can cause irritation to the nasal passages, mouth, eyes and throat, and ingesting high $\mathrm{Cu}$ concentrations can lead to nausea, vomiting and diarrhoea. Exposure to very high levels can damage the liver and kidneys and may lead to death. Copper is classified as a hazardous substance. An excess of $\mathrm{Cu}$ may result in Wilson's disease, mostly ending in death (Sharma et al. 2009).

Fungicides have received little attention compared with other types of pesticides, such as insecticides and herbicides, despite the likely environmental risks (Wightwick et al. 2010). Ecological risks of chemicals detected in the environment are often derived by comparisons with environmental quality values and reported ecotoxicological effects values for key sentinel aquatic species (Wightwick et al. 2012). The paucity of ecotoxicological data for fungicides is surprising given their frequency of use and the fact that most do not have specific modes of action and thus are likely to be toxic to a wide range of organisms, not just fungi (Maltby et al. 2009). There is a widespread presence of residues of many different organic fungicide compounds in the surface waters of a horticultural-production catchment. Whilst, it appears that the fungicides detected are likely to pose a low ecological risk to fish, aquatic invertebrates, and algae, it is important to note that at present there are few ecotoxicological data available describing the effects of fungicides on aquatic fungi and microorganisms despite the fact that these organisms are likely sensitive to fungicides and play a key role in aquatic ecosystems (e.g., decomposition and nutrient cycling) (Milenkovski et al. 2010) as reviewed by Wightwick et al. (2012).

\section{Possible recommendations}

It could be recommended that, phosphate application to soils such as fertilizers can reduce the mobility of risk metals through sorption mechanisms on newly formed phases, but probably not through precipitation of $\mathrm{Cu}$-phosphates as observed, for example, for $\mathrm{Pb}$-phosphates (Pérez-Novo et al. 2009). It could be also recommended that, some management options (e.g., lime, organic matter,...ect.) are applied to soils in residential areas with a total concentration in excess of $\mathrm{Cu}$ of $300 \mathrm{mg} \mathrm{kg}^{-1}$, because this concentration represents a threat to humans health (Cornforth et al. 2003). On the other hand, lime should be applied to the acidic soils to increase the $\mathrm{pH}$ from 6.5 to 7.0 and the organic matter concentration should be maintained or increased by applying organic materials 
such as compost or peat. Orchard and vineyard soils should be cultivated to mix the topsoil and thus dilute the large concentrations of $\mathrm{Cu}$ found in the surface few centimetres (Cornforth et al. 2003).

It is indicated that, threshold values of total $\mathrm{Cu}$ and exchangeable $\mathrm{Cu}$ contents indicative of soil $\mathrm{Cu}$ pollution cannot be established. However, adequate management practices resulting in soil organic $\mathrm{C}$ contents $>2 \%$ and $\mathrm{pH}$ $>5.5$ are recommended for preserving vineyard soil quality (Soler-Rovira et al. 2013).

Significant adverse effects were only found for three bioassays in vineyard samples of one site and for two bioassays in another site. Biological responses in these cases were more importantly explained by other soil properties than soil $\mathrm{Cu}$. Overall, no $\mathrm{Cu}$ toxicity to plants, microbial processes and invertebrates was observed in vineyard soil samples at $\mathrm{Cu}$ concentrations well above European Union limits protecting the soil ecosystem (Ruyters et al. 2013).

It could be provided valuable information for policy and decision-makers, all over the world, to assess the likely risks the use of fungicide compounds in horticultural production systems poses to aquatic ecosystems. To progress toward a more thorough assessment of the ecological risks posed, future research should focus on gaining a better understanding of the ecotoxicological effects of priority fungicides and fungicide mixtures, particularly to the lower trophic levels of aquatic ecosystems (Wightwick et al. 2012).

\section{Conclusions}

It could be concluded that, $\mathrm{Cu}$ compounds applied as pesticides to horticultural soils accumulate in the upper soil layers and some $\mathrm{Cu}$ in these soils is attached very strongly to soil particles and organic materials making it unavailable to plants. Despite its environmental and agricultural importance, the concentration, distribution and fractionation of anthropogenic, and naturally occurring, $\mathrm{Cu}$ in soils is poorly known. Ecological risks of chemicals detected in the environment are often derived by comparisons with environmental quality values and reported ecotoxicological effects values for key sentinel aquatic species and soil organisms. The paucity of ecotoxicological data for fungicides is surprising given their frequency of use and the fact that most do not have specific modes of action and thus are likely to be toxic to a wide range of organisms, not just fungi. The threshold values of total $\mathrm{Cu}$ and exchangeable $\mathrm{Cu}$ contents indicative of soil $\mathrm{Cu}$ pollution cannot be established. However, adequate management practices resulting in soil organic $\mathrm{C}$ contents $>2 \%$ and $\mathrm{pH}>$ 5.5 are recommended for preserving vineyard soil quality.

\section{Acknowledgments}

Authors acknowledge the Hungarian Ministry of Education and Culture (Hungarian Scholarship Board, HSB and the Balassi Institute) and the Egyptain Ministry of
Higher Education for funding and supporting this work. They also thank Prof. Dr. Dr. Ewald Schnug, President of the International Scientific Centre of Fertilizers (CIEC), and Institute for Crop and Soil Science, JKI, Federal Research Centre for Cultivated Plants, Braunschweig, Germany for his support and help. The authors also acknowledge Dr. Sabry Shaheen for his support and revising this work.

\section{References}

Adriano, D. C. (2001). Trace elements in the terrestrial environments: biogeochemistry, bioavailability, and risks of metals. New York-Berlin-Heidelberg-Tokyo: Springer - Verlag.

Allen, H. E. (1993). The significance of trace metal speciation for water, sediment and soil quality criteria and standards. Sci. Total Environ. Suppl.1:23-45.Alloway B. J. (1995). Heavy metals in soils. $2^{\text {nd }}$ ed., Chapman \& Hall, London.

Aoyama, M. and T. Nagumo (1997). Comparison of the effects of $\mathrm{Cu}, \mathrm{Pb}$, and $\mathrm{As}$ on plant residue decomposition, microbial biomass and soil respiration. Soil Science and Plant Nutrition 43: 613-622.

Baroux, J. (1972). Toxicity of copper on ammonification phenomena in soils of Bordeaux vineyards. C R Hebd Seances Acad Sci Ser D 275: 499-502.

Bending, G. D., M. K. Turner, F. Rayns, M. C. Marx and M. Wood (2004). Microbial and biochemical soil quality indicators and their potential for differentiating areas under contrasting agricultural management regimes. Soil Biology \& Biochemistry 36: $1785-1792$.

Besnard, E., C. Chenu and M. Robert (1999). Distribution of copper in vineyard soils, as influenced by organic amendments. Symposium J09-Environmental Pollution and Natural Backgrounds. Journal of Conference Abstracts (Cambridge Publications).

Bolan, N., D. Adriano, S. Mani and A. Khan (2003). Adsorption, complexation and phytoavailability of copper as influenced by organic manure. Environmental Toxicology and Chemistry 22: 450-456.

Bouazizi, H., H. Jouili, A. Geitmann and E. E. I. Ferjani (2010). Copper toxicity in expanding leaves of Phaseolus vulgaris L.: antioxidant enzyme response and nutrient element uptake. Ecotox. Environ. Safe., Vol. 73 (6): 1304-1308.

Bradl, H. B. (2004). Adsorption of heavy metal ions on soils and soils constituents. J Colloid Interf Sci 277: 1-18.

Broadley, M., P. Brown, I. Cakmak, Z. Rengel and F. Zhao (2012). Function of Nutrients: Micronutrients. In: P. Marschner (Ed.) Marschner's Mineral Nutrition of Higher Plants. DOI:10.1016/ B978-0-12-384905-2.00007-8. pp: 191 - 248.

Brookes, P. C. (1995). The use of microbial parameters in monitoring soil pollution by heavy metals. Biology and Fertility of Soils 19: 269-279.

Brooks, R. R. (1977). Copper and cobalt uptake by Haumaniastrum species. Plant Soil 48: 541-544.

Brooks, R. R., S. D. Naidu, F. Malaisse and J. Lee (1987). The elemental content of metallophytes from the copper/cobalt deposits of Central Africa, Bull. Soc. roy. Bot. Belg. 119: 179-191.

Casali, C. A., D. F. Moterle, D. S. Rheinheimer, G. Brunetto, A. L. M. Corcini, J. Kaminski, et al. (2008). Copper forms and desorption in soils under grapevine in the Serra Gaúcha of Rio Grande do Sul. R Bras Ci Solo, 32: 1479-87. 
Chaignon, V., I. Sanchez-Neira, P. Herrmann, B. Jaillard and P. Hinsinger (2003). Copper bioavailability and extractability as related to chemical properties of contaminated soils from a vinegrowing area. Environmental Pollution 123: 229-238.

Chopin, E. I. B., B. Marin, R. Mkoungafoko, A. Rigaux, M. J. Hopgood, E. Delannoy, B. Cancès, and M. Laurain (2008). Factors affecting distribution and mobility of trace elements $(\mathrm{Cu}$, $\mathrm{Pb}, \mathrm{Zn}$ ) in a perennial grapevine (Vitis vinifera $\mathrm{L}$.) in the Champagne region of France. Environ Pollut 156: 1092-8.

Cornforth, I. S., W. T. Bussell and J. R. Lewthwaite (2003). Significance of soil copper in the urban development of horticultural soils, New Zealand Journal of Crop and Horticultural Science, 31 (4): 293-302.

Dell'Amico, E., M. Mazzocchi, M. Cavalca, L. Allievi, V. Andreoni (2008). Assessment of bacterial community structure in a long-term copper-polluted ex-vineyard soil. Microbiol Res 163: 671-83.

Deluisa, A., P. Giandon, M. Aichner, P. Bortolami, A. Bruna, A. Lupetti, F. Nardelli and G. Stringari (1996). Copper pollution in Italian vineyard soils. Commun. Soil. Sci. Plant Anal., 27, 1537.

Díaz-Raviña, M., R. Calvo de Anta and E. Bååth (2007). Tolerance (PICT) of the bacterial communities to copper in vineyards soils from Spain. J Environ Qual, 36: 1760-4.

Dousset, S., A. R. Jacobson, J. B. Dessogne, N. Guichard, P. C. Baveye and F. Andreux (2007). Facilitated transport of diuron and glyphosate in high copper vineyard soils. Environ Sci Technol, 41:8056-61.

Dykeman, W. R. and A. S. De Sousa (1966). Natural mechanisms of copper tolerance in a copper swamp, Can. J. Bot. 44: 871-878.

EC, European Commission (2002). EC (European Commission) regulation 473/2002 amending Annexes I, II and VI to Council Regulation (EEC) No 2092/91 on organic production of agricultural products and indications referring thereto on agricultural products and foodstuffs, and laying down detailed rules as regards the transmission of information on the use of copper compounds.

Eckel, H., U. Roth, H. Dohler, et al. (2005). Assessment and reduction of heavy metal input into agro-ecosystems. Final Rep. Eu-Concerted Action AROMIS, KTBL-Schrift, Darmstadt.

Epstein, E. and A. J. Bloom (2005). Mineral Nutrition of Plants: Principles and Perspectives, $2^{\text {nd }}$ ed. Sunderland, Mass.: Sinauer.

Fernández-Calviño, D., A. Martín, M. Arias-Estévez, E. Bååth, M. Díaz-Raviña (2010b). Microbial community structure of vineyard soils with different $\mathrm{pH}$ and copper content. Appl Soil Ecol, 46: 276-82.

Fernández-Calviño, D., C. Pérez-Novo, J. C. Nóvoa-Muñoz and M. Arias-Estévez (2009b). Copper fractionation and release from soils devoted to different crops. Journal of Hazardous Materials 167: 797-802.

Fernández-Calviño, D., E. López-Periago, J. C. Nóvoa-Muñoz and M. Arias-Estévez (2008c). Short scale distribution of copper fractions in a vineyard acid soil. Land Degrad Dev 19: 190-7.

Fernández-Calviño, D., J. A. Rodríguez-Suárez, E. LópezPeriago, M. Arias-Estévez and J. Simal-Gándara (2008b). Copper content of soils and river sediments in a winegrowing area, and its distribution among soil or sediment components. Geoderma 145: 91-7.

Fernández-Calviño, D., J. C. Nóvoa-Muñoz, E. López-Periago and M. Arias-Estévez (2008d). Changes in copper content and distribution in young, old and abandoned vineyard acid soils due to land changes. Land Degrad Dev 19: 165-77.

Fernández-Calviño, D., J. C. Nóvoa-Muñoz, M. Díaz-Raviña and M. Arias-Estévez (2009a). Copper accumulation and fractionation in vineyard soils from temperate humid zone (NW Iberian Peninsula). Geoderma 153: 119-129.

Fernández-Calviño, D., J. Rousk, P. C. Brookes, E. Bååth (2011b). Bacterial $\mathrm{pH}$-optima for growth track soil $\mathrm{pH}$, but are higher than expected at low pH. Soil Biol Biochem, 43:1569-75.

Fernández-Calviño, D., M. Arias-Estévez, M. Díaz-Raviña, E. Bååth (2011a). Bacterial pollution induced community tolerance (PICT) to $\mathrm{Cu}$ and interactions with $\mathrm{pH}$ in long-termpolluted vineyard soils. Soil Biol Biochem, 43: 2324-31.

Fernández-Calviño, D., M. Pateiro-Moure, E. López-Periago, M. Arias-Estévez and J. C. Nóvoa-Muñoz (2008a). Copper distribution and acid-base mobilization in vineyard soils and sediments from Galicia (NW Spain). Eur J Soil Sci 59: 315-26.

Fernández-Calviño, D., P. Soler-Rovira, A. Polo, M. DíazRaviña, M. Arias-Estévez, C. Plaza (2010a). Enzyme activities in vineyard soils long-term treated with copper-based fungicides. Soil Biol Biochem, 42: 2119-27.

Gaw, S. K. (2002). Pesticide residues in horticultural soils in the Auckland Region. Working Report No. 96. Auckland, Auckland Regional Council. 91 p.

Gunkel, P., E. Roth and B. Fabre (2003). Copper distribution in chemical soil fractions and relationships with maize crop yield. Environ Chem Lett, 1:92-97.

He, Z. L., X. E. Yang and P. J. Stoffella (2005). Trace elements in agroecosystems and impacts on the environment. Journal of Trace Elements in Medicine and Biology 19: 125-140.

He, Z., J. Fan, X. Yang and P. J. Stoffella (2010). Soil amendment to remediate copper contaminated soils. $19^{\text {th }}$ World Congress of Soil Science, Soil Solutions for a Changing World $1-6$ August 2010, Brisbane, Australia, pp: 227 - 230.

Herrero-Hernández, E., M. S. Andrades, M. S. Rodríguez-Cruz, M.Arienzo and M. J. Sánchez-Martín (2011). Long-term variability of metals from fungicides applied in amended young vineyard fields of La Rioja (Spain). Environmental Monitoring Assessment, 1-13.

James, R. O. and N. J. Barrow (1981). Copper interactions with inorganic constituents of soils. In: Loneragan, J. F.; Robson, A. D.; Graham, R. D. (ed.) Copper in soils and plants. Sydney, Academic Press. Pp. 287-312.

Jones, J. B. Jr. (2003). Agronomic handbook - Management of crops, soils, and their fertility. CRC Press, Boca Raton, FL.

Jones, J. B. Jr. (2005). Hydroponics - A Practical Guide for the Soilless Grower. $2^{\text {nd }}$ Edition. CRC PRESS, Boca Raton London New York Washington, D.C.

Kabata-Pendias, A. (2011). Trace elements in soils and plants, $4^{\text {th }}$ ed., CRC Press, Boca Raton, FL. Taylor and Francis Group, LLC.

Kabata-Pendias, A. and A. B. Mukherjee (2007). Trace elements from soil to human. Springer Science + Business Media, SpringerVerlag Berlin Heidelberg.

Kabata-Pendias, A. and W. Sadurski (2004). Trace elements and compounds in soil. In: Elements and Their Compounds in the Environment (eds.), E. Merian, M. Anke, M. Ihnat, M. Stoeppler, 79-99, Wiley-VCH, Weinheim.

Karlsson, T., P. Persson and U. Skyllberg (2006). Complexation of copper (II) in organic soils and in dissolved organic matter - 
EXAFS evidence for chelate ring structures. Environ Sci Technol 40: 2623-8.

Kirkby, E. (2012). Introduction, definition and classification of nutrients. In: Marschner's Mineral Nutrition of Higher Plants, (ed. Petra Marschner) DOI:10.1016/B978-0-12-384905-2.00001-7, Elsevier Ltd., p: 1 - 5.

Komárek, M., E. Čadková, V. Chrastný, F. Bordas, J.-C. Bollinger (2010). Contamination of vineyard soils with fungicides: A review of environmental and toxicological aspects. Environment International, 36: 138-151. doi:10.1016/j.envint.2009.10.005.

Komárek, M., J. Balík, V. Chrastný, J. Száková (2009). Distribution and fractionation of copper in contaminated hop field soils. Fresenius Environ Bull 18: 1319-23.

Lequeux, H., C. Hermans, S. Lutts and N. Verbruggen (2010). Response to copper excess in Arabidopsis thaliana: Impact on the root system architecture, hormone distribution, lignin accumulation and mineral profile. Plant Physiol. Biochem. 48: 673-682.

Li, W., M. Zhang and H. Shu (2005). Distribution and fractionation of copper in soils of apple orchards. Environ Sci Pollut Res, 12: $168-72$

Lindsay, W. L. (1979). Chemical equilibria in soils. New YorkChichester-Brisbane-Toronto: John Wiley \& Sons.

Logan E. M., I. D. Pulford, G. T. Cook and A. B. Mackenzie (1997). Complexation of $\mathrm{Cu}^{2+}$ and $\mathrm{Pb}^{2+}$ by peat and humic acid. Eurasian J. Soil Sci. 48: 685-696.

Loland, J. O. and B. R. Singh (2004). Copper contamination of soil and vegetation in coffee orchards after long-term use of $\mathrm{Cu}$ fungicides. Nutr Cycl Agroecosys, 69: 203-11.

Ma, Y. B., E Lombi., A. L. Nolan and M. McLaughlin (2006). Short-term natural attenuation of copper in soils: effect of time, temperature, and soil characteristics. Environ. Toxic. Chem. 25:652-658.

Mackie, K. A., T. Müller and E. Kandeler (2012). Remediation of copper in vineyards: A mini review. Environmental Pollution, 167: 16-26. doi:10.1016/j.envpol.2012.03.023.

Malaisse, F. and J. Gregoire (1978). Contribution a la phytogeochimie de la Mine de l'Etoile (Shaba, Zaire), Bull. Soc. roy. Bot. Belg. 111: 252-260.

Malaisse, F., J. Gregoire, R. R. Brooks, R. S. Morrison and R. D. Reeves, (1979). Copper and cobalt in vegetation of Fungurume, Shaba Province, Zaire, Oikos 33: 472-478.

Malaisse, F., R. R. Brooks and A. J. M. Baker (1994). Diversity of vegetation communities in relation to soil heavy metal content at the Shinkolobwe copper/cobalt/uranium mineralization, Upper Shaba, Zaire, Belg. J. Bot. 127: 3-16.

Maltby, L., T. C. M. Brock, P. J. van den Brink (2009). Fungicide risk assessment for aquatic ecosystems: importance of interspecific variation, toxic mode of action, and exposure regime. Environ Sci Technol 43: 7556-7563

Manivasagaperumal, R., P. Vijayarengan, S. Balamurugan and G. Thiyagarajan (2011). Effect of Copper on Growth, Dry Matter Yield and Nutrient Content of Vigna radiata (L.) Wilczek. Journal of Phytology, Vol. 3(3): 53-62.

Marschner, H. (2002). Mineral nutrition of higher plants. $2^{\text {nd }}$ Edition, Elsevier Academic Press, London, UK.

Martin, N. A. (1986). Toxicity of pesticides to Allobophera caliginosa (Oligochaeta: Lumbricidar). New Zealand Journal of Agricultural Research 29: 699-706.
Martínez-Villegas, N. and C. E. Martínez (2008). Solid- and solution-phase organics dictate copper distribution and speciation in multicomponent systems containing ferrihydrite, organic matter, and montmorillonite. Environ Sci Technol 42: 2833-8.

Mengel, K.; E. A. Kirkby; H. Kosegarten; T. Appel (2001). Principles of plant Nutrition. $2^{\text {nd }}$ Edition, International Potash Inst., Berne, Switzerland.

Merry, R. H., K. G. Tiller and A. M. Alston (1983). Accumulation of copper, lead and arsenic in some Australian orchard soils. Australian Journal of Soil Research 21: 549-561.

Michaud, A. M., M. N. Bravin, M. Galleguillos and P. Hinsinger (2007). Copper uptake and phytotoxicity as assessed in situ for durum wheat (Triticum turgidum durum L.) cultivated in $\mathrm{Cu}-$ contaminated, former vineyard soils. Plant Soil 298: 99-111.

Miko, S., G. Koch, S. Mesič, M. M. Šparica, M. Šparica, P. Vreča, and T. Dolenec (2007). Influence of land use in small karst watersheds on the chemical status of peloid sediments on the eastern Adriatic coast. J Soils Sediments 7: 303-12.

Milenkovski, S., E. Baath, P. E. Lindgren and O. Berglund (2010). Toxicity of fungicides to natural bacterial communities in wetland water and sediment measured using leucine incorporation and potential denitrification. Ecotoxicology 19: 285-294.

Mirlean, N., A. Roisenberg and J. O. Chies (2007). Metal contamination of vineyard soils in wet subtropics (southern Brazil). Environ Pollut, 149: 10-7.

Mirlean, N., P. Baisch and S. Medeanic (2009). Copper bioavailability and fractionation in coppercontaminated sandy soils in the wet subtropics (southern Brazil). B Environ Contam Tox 82: 373-7.

Nannipieri, P., J. Ascher, M. T. Ceccherini, L. Landi, G. Pietramellara and G. Renella (2003). Microbial diversity and soil functions. Eur J Soil Sci, 54:655-70.

Nóvoa-Muñoz, J. C., J. M. G. Queijeiro, D. Blanco-Ward, C. Álvarez-Olleros, A. Martínez-Cortizas, E. and García-Rodeja (2007). Total copper content and its distribution in acid vineyards soils developed from granitic rocks. Sci Total Environ 378: $23-7$.

Paoletti, M. G., D. Sommaggio, G. Petruzzelli, B. Pezzarossa and M. Barbafieri (1998). Earthworms as useful bioindicators of ecosystem sustainability in orchards and vineyards with different inputs. Applied Soil Ecology 10: 137-150.

Paradelo, M., M. Arias-Estévez, J. C. Nóvoa-Muñoz, P. PérezRodríguez, A. Torrado-Agrasar and J. López-Periago (2008). Simulating washoff of Cu-based fungicide sprays by using a rotating shear device. J Agric Food Chem 56: 5795-800.

Parat, C., R. Chaussod, J. Lévêque, S. Dousset and F. Andreux (2002). The relationship between copper accumulated in vineyard calcareous soils and soil organic matter and iron. Eur J Soil Sci 53: 663-9.

Pateiro-Moure, M., C. Pérez-Novo, M. Arias-Estévez, E. LópezPeriago, E. Martínez-Carballo and J. Simal-Gándara (2007). Influence of copper on the adsorption and desorption of paraquat, diquat, and difenzoquat in vineyard acid soils. J Agric Food Chem, 55: 6219-26.

Pérez-Novo, C., A. Bermúdez-Couso, E. López-Periago, D. Fernández-Calviño and M. Arias-Estévez (2009). The effect of phosphate on the sorption of copper by acid soils. Geoderma 150 : 166-70.

Pietrzak, U. and D. C. McPhail (2004). Copper accumulation, distribution and fractionation in vineyard soils of Victoria, Australia. Geoderma 122: 151-166. 
Pociecha, M. and D. Lestan (2009). EDTA leaching of $\mathrm{Cu}$ contaminated soil using electrochemical treatment of the washing solution. J Hazard Mater 165: 533-9.

Ponizovky, A. A., H. E. Allen and A. J. Ackerman (2007). Copper activity in soil solutions in calcareous soils. Environ. Pollut. 145:1-6.

Ponizovsky, A. A., S. Thakali, H. E. Allen, D. M. Di Toro and A. J. Ackerman (2006). Effect of soil properties on copper release in soil solution at low moisture content. Environ. Toxic. Chem. 25:671-682.

Prasad, B. R., S. Basavaiah, A. Subba Rao, I. V. Subba Rao (1984). Forms of copper in soils of grape orchards. Journal of the Indian Society of Soil Science 32: 318-322.

Probst, B., C. Schüler and R. G. Joergensen (2008). Vineyard soils under organic and conventional management-microbial biomass and activity indices and their relation to soil chemical properties. Biol Fertil Soils 44: 443-50.

Provenzano, M. R., H. El Bilali, V. Simeone, N. Baser, D. Mondelli, and G. Cesari (2010). Copper contents in grapes and wines from a Mediterranean organic vineyard. Food Chemistry 122: 1338-1343.

Reeves, R. D. (2006). Hyperaccumulation of trace elements by plants. In: J.-L. Morel, G. Echevarria and N. Goncharova (eds.), Phytoremediation of Metal-Contaminated Soils, 25-52. Springer, NATO Science Series, Series IV: Earth and Environmental Sciences - Vol. 68.

Reeves, R. D. and A. J. M. Baker (2000). Metal-accumulating plants. In: I. Raskin and B. D. Ensley (eds.), Phytoremediation of Toxic Metals: Using Plants to Clean Up the Environment, Wiley, New York.

Rusjan, D. (2012). Copper in Horticulture. In: Fungicides for Plant and Animal Diseases, Dharumadurai Dhanasekaran (Ed.), ISBN: 978-953-307-804-5, InTech, Available from: http://www. intechopen.com/books/fungicides-for-plant-and-animal-diseases/ copper-in-horticulture.

Rusjan, D., M. Strlič, D. Pucko and Z. Korošec-Koruza (2007). Copper accumulation regarding the soil characteristics in subMediterranean vineyards in Slovenia. Geoderma, 141: 111-8.

Ruyters, S., P. Salaets, K. Oorts and E. Smolders (2013). Copper toxicity in soils under established vineyards in Europe: A survey. Science of the Total Environment, 443: 470-477. http://dx.doi. org/10.1016/j.scitotenv.2012.11.001.

Sayen, S., J. Mallet and E. Guillon (2009). Aging effect on the copper sorption on a vineyard soil: column studies and SEM-EDS analysis. J Colloid Interface Sci 331: 47-54.

Schuler, L. J. and T. C. Hoang (2008). Aquatic risk assessment of copper in freshwater and saltwater ecosystem of south Florida. Ecotoxicology 17: 642-659.

Sharma, S. K., N. S. Sehkon, S. Deswal and S. John (2009). Transport and Fate of Copper in Soils. International Journal of Civil and Environmental Engineering, Vol. 1 1:6.

Soler-Rovira, P., D. Fernández-Calviño, M, Arias-Estévez, C. Plaza and A. Polo (2013). Respiration parameters determined by the ISO-17155 method as potential indicators of copper pollution in vineyard soils after long-term fungicide treatment. Science of the Total Environment 447: 25-31. doi.org/10.1016/j. scitotenv.2012.12.07.
Strawn, D. G. and L. L. Baker (2008). Speciation of $\mathrm{Cu}$ in a contaminated agricultural soil measured by XAFS, $\mu$-XAFS, and $\mu$-XRF. Environ Sci Technol 42: 37-42.

Strawn, D. G. and L. L. Baker (2009). Molecular characterization of copper in soils using X-ray absorption spectroscopy. Environ Pollut 157: 2813-21.

Toselli, M., E. Baldi, G. Marcolini, D. Malaguti, M. Quartieri, G. Sorrenti and B. Marangoni (2009). Response of potted grapevines to increasing soil copper concentration. Australian J. Grape Wine Research, 15: 85-92.

Turnlund, J., R. Jacob, C. Keen, J. J. Strain, D. Kelley, J. Domek, W. Keyes, J. Ensunsa, J. Lykkesfeldt and J. Coulter (2004). Long-term high copper intake: effects on indexes of copper status, antioxidant status, and immune function in young men. Am. J. Clinical Nutr., 79: 1037-1044.

Upadhyay, R. K. and S. K. Panda (2009). Copper-induced growth inhibition, oxidative stress and ultra-structural alterations in freshly grown water lettuce (Pistia stratiotes L.). CRBiol. 332: 623-632.

USGS, U.S. Geological Survey (2013). Mineral commodity summaries 2013. http://minerals.usgs.gov/minerals/pubs/mcs/2013/ mcs2013.pdf/ 26.1.2013.

Van Zwieten, L., J. Rust, T. Kingston, G. Merrington and S. Morris (2004). Influence of copper fungicide residues on occurrence of earthworms in avocado orchard soils. Sci Total Environ 329: 29-41.

Viti, C., D. Quaranta, R. De Philippis, G. Corti, A. Agnelli, R. Cuniglio and L. Giovannetti (2008). Characterizating cultivable soil microbial communities from copper fungicide-amended olive orchard and vineyard soils. World Journal of Microbiology and Biotechnology 24: 309-318.

Wang, Q.-Y., D.-M. Zhou and L. Cang (2009). Microbial and enzyme properties of apple orchard soil as affected by long-term application of copper fungicide. Soil Biology \& Biochemistry 41: 1504-1509. doi:10.1016/j.soilbio.2009.04.010.

Wei, X. R., M. D. Hao and M. A. Shao (2007). Copper fertilizer effect on copper distribution and vertical transport in soils. Geoderma 138: 213-220.

Wightwick, A, R. Walters, G. Allinson, S. M. Reichman and N. W. Menzies (2010). Environmental risks of fungicides used in horticultural production systems. In: Carisse O (ed.) Fungicides. InTech, Reijka, pp 273-304.

Wightwick, A. M., A. D. Bui, P. Zhang, G. Rose, M. Allinson, J. H. Myers, S. M. Reichman, N. W. Menzies, V. Pettigrove and G. Allinson (2012). Environmental fate of fungicides in surface waters of a horticultural-production catchment in Southeastern Australia. Arch Environ Contam Toxicol 62: 380-390. DOI 10.1007/s00244011-9710-y.

Wightwick, A., M. Mollah, D. Partington, G. Allinson (2008). Copper fungicide residues in Australian vineyard soils. J Agric Food Chem 56: 2457-2464.

Yu, S., Z. L. He, C. Y. Huang, G. C. Chen and D. V. Calvert (2004). Copper fractionation and extractability in two contaminated variable charge soils. Geoderma 123: 163-175. doi:10.1016/j. geoderma.2004.02.003.

Zhou, L. X. and J. W. C. Wong (2003). Behavior of heavy metals in soils: effect of dissolved organic matter. In: Geochemical and Hydrological Reactivity of Heavy Metals in Soil, ed. H.M. Selim, W.L. Kingery, 245-269, Lewis Publ., Chelse, MI. 